\title{
Three Species of Processid Shrimps (Crustacea: Decapoda: Caridea) from Korea
}

\author{
Jung Nyun Kim*, Jung Hwa Choi, Kangseok Hwang, \\ Taeg Yun Oh, Kwang Ho Choi, Dong Woo Lee
}

Fisheries Resources Management Division, National Fisheries Research and Development Institute, Busan 619-705, Korea

\begin{abstract}
Three species of the family Processidae, Hayashidonus japonicus (De Haan, 1844), Processa sulcata Hayashi, 1975 and Processa zostericola Hayashi, 1975 described with illustrations from Korea. Two of these species, $H$. japonicus and $P$. zostericola, represent new records for the Korean carcinological fauna. The genus Hayashidonus included the single species, H. japonicus is distinguished from other genera of Processidae by the broadly triangular rostrum, the obscure or absent dorsolateral spines of the telson, and the exceptionally long molar process of the mandible. Two species of the genus Processa, P. zostericola and P. sulcata are distinguishable each other by presence or absence of an obtuse process of the basicerite of antenna on the anteroventral margin. The basicerite of antenna arms with the obtuse process in $P$. zostericola, while in $P$. sulcata the basicerite of antenna lacks the process but is smooth on the ventral margin. A key to these species is presented.
\end{abstract}

Keywords: Hayashidonus japonicus, Processa sulcata, Processa zostericola, Processidae, Decapoda, Korea

\section{INTRODUCTION}

The family Processidae is characterized by a chelate right first pereopod and a simple left pereopod usually terminating in a plain claw-like dactylus. If both first pereopods are chelate, the rostrum shows a distal setose notch formed by a subdistal dorsal tooth with no other teeth (Holthuis, 1993). The processid shrimps commonly occur in pantropical and subtropical regions and occasionally in temperate regions. They are usually confined to shallow grass flats and tide pools (Chace, 1997).

The family includes five genera and 65 species (De Grave et al., 2009). Only one, Processa sulcata Hayashi, 1975, has been reported from Korean waters (Cha et al., 2001).

During the course of a taxonomic study of Korean decapod crustaceans, three species of Processidae, Hayashidonus japonicus (De Haan, 1844), Processa sulcata Hayashi, 1975, and Processa zostericola Hayashi, 1975, were collected from the southern coastal waters of Korea, included Jeju Island. This report provides the first record of these species, except for $P$. sulcata, in Korean waters. All three species are describ-

(c) This is an Open Access article distributed under the terms of the Creative Commons Attribution Non-Commercial License (http://creativecommons.org/ licenses/by-nc/3.0/) which permits unrestricted non-commercial use, distribution, and reproduction in any medium, provided the original work is properly cited. ed and illustrated, and an identification key is provided.

The specimens described in this study were deposited in the National Fisheries Research and Development Institute (NFRDI). Specimen sizes are based on postorbital carapace length (CL), and the terminology of the descriptions mainly follows that of Chace (1997).

\section{SYSTEMATIC ACCOUNTS}

Order Decapoda Latreille, 1802

Infraorder Caridea Dana, 1852

Family Processidae Ortmann, 1896

1*Genus Hayashidonus Chace, 1997

${ }^{2 *}$ Hayashidonus japonicus (De Haan, 1844) (Fig. 1)

\section{Restricted synonymy}

Nika japonica De Haan, 1844, pl. 46, fig. 6 (type locality: Japan); 1849: 184, pl. N.

Processa japonica: Hayashi, 1975: 110, fig. 24 (see full
*To whom correspondence should be addressed

Tel: 82-51-720-2331, Fax: 82-51-720-2337

E-mail: crangonk@nfrdi.go.kr 


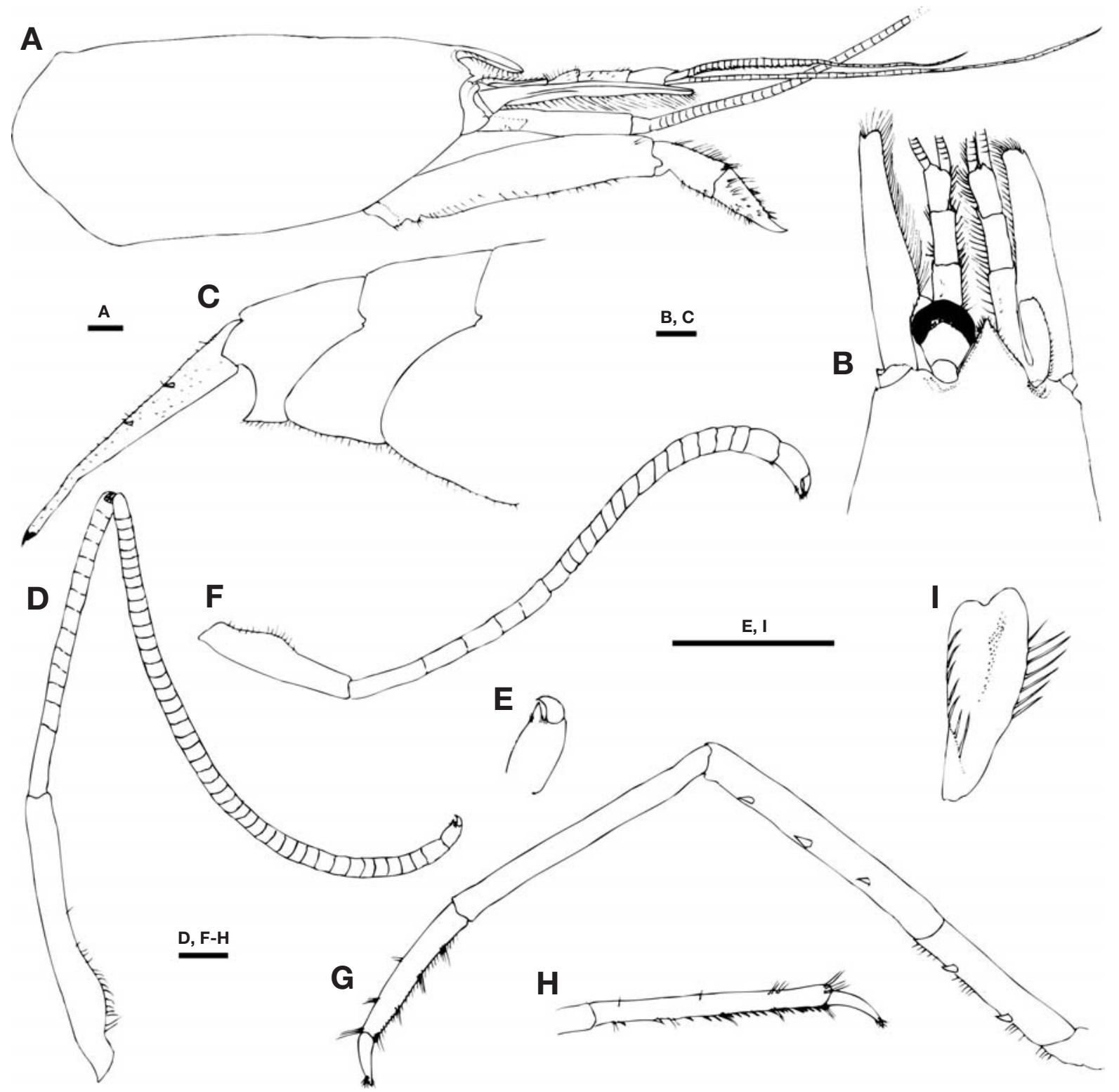

Fig. 1. Hayashidonus japonicus (De Haan, 1844). A-H, Ovigerous female (CL 12.2 mm, NFRDI 20110802-1) from Aenggang Bay, Isl. Namhae; I, male (CL 6.8 mm, NFRDI 20110802-2) from Hamduok, Jeju-do. A, Carapace, cephalic appendages and third maxilliped, lateral, eye omitted; B, Anterior carapace and cephalic appendages, dorsal, right eye omitted; C, Fourth to sixth abdominal somites and telson, lateral; D, Right second pereopod, lateral; E, Same, chela, lateral; F, Left second pereopod, lateral; G, Right third pereopod, lateral; H, Dactylus and propodus of left fifth pereopod, lateral; I, Endopod of left first pleopod, ventral. CL, postorbital carapace length; NFRDI, National Fisheries Research and Development Institute. Scale bars: A-I=1 mm.

synonymy); Noël, 1986: 287.

Hayashidonus japonicus: Chace, 1997: 35, fig. 18.

Material examined. Korea: Gyeongsangnam-do: 2 우 우 (CL $11.5,11.8 \mathrm{~mm}$ ), 1 ovig. 우 (CL $12.2 \mathrm{~mm}$ ), Namhae Island, Aenggang Bay, Zostera belt, beam trawl, 19 May 2005, Kim HW, NFRDI 20110802-1; Jeju-do: $1 \sigma^{\nearrow}$ (CL 6.8 mm), Hamduok, Zostera belt, beam trawl, 10 Jun 1994, Kim JN, NFRDI
20110802-2.

Description. Integument glabrous, except for pubescent telson. Rostrum (Fig. 1A, B) short, 0.17-0.23 times as long as carapace, broad, triangular in dorsal aspect, not bifid distally, lateral margin rather strongly carinate. Carapace (Fig. 1A, B) almost smooth; postorbital region slightly grooved; antennal spine small but acute. Abdominal somites (Fig. 1C) smooth and rounded; pleura of first to fifth somites unarmed; lateral 


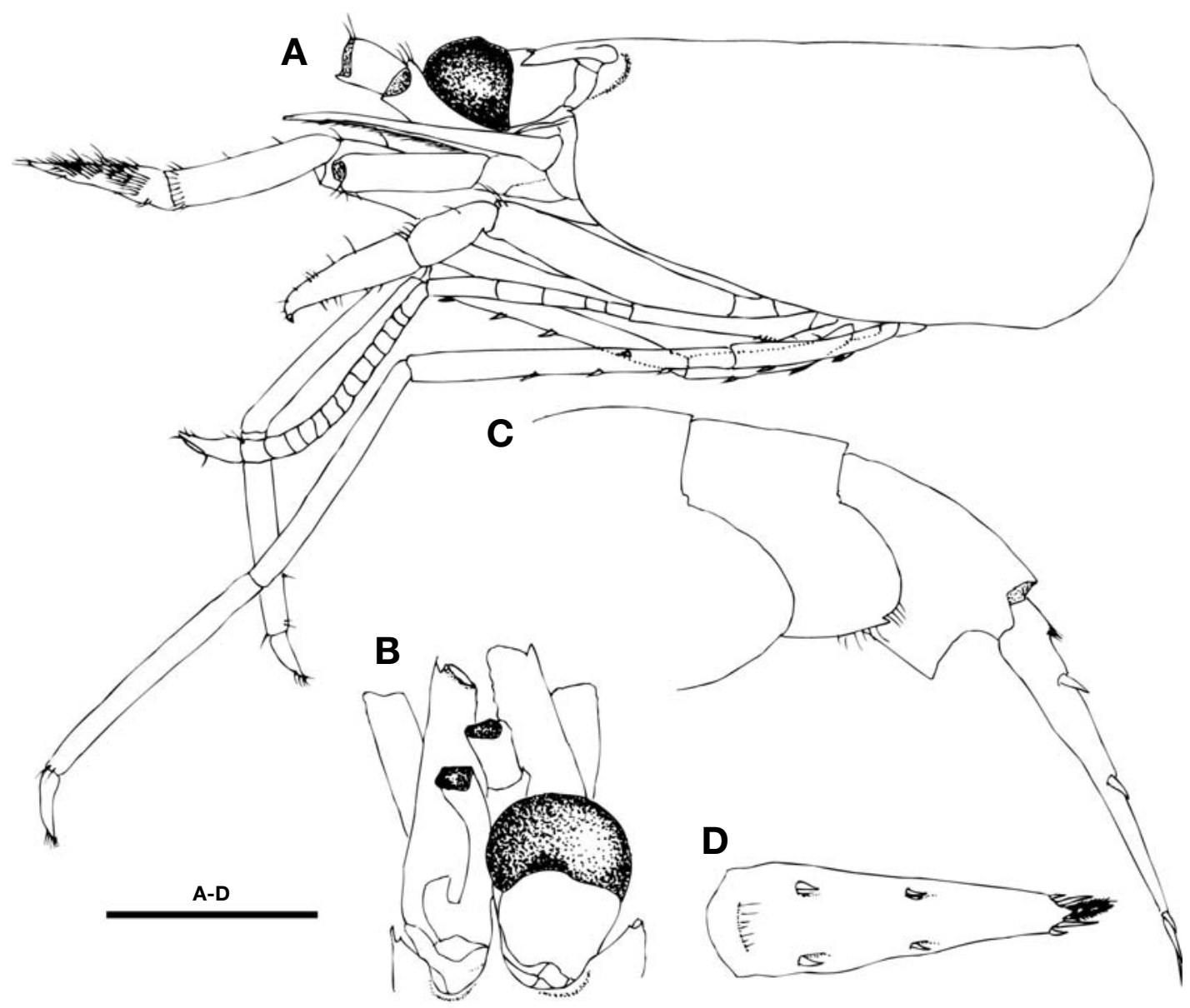

Fig. 2. Processa sulcata Hayashi, 1975. A, B, Sex unknown (CL 2.5 mm, NFRDI 20110802-3); C, D, Sex unknown (CL 3.0 mm, same lot) from Gujora, Isl. Geoje. A, Carapace, cephalic and thoracic appendages, fifth pereopods missing, lateral; B, Anterior carapace and cephalic appendages, dorsal, left eye omitted; C, Fourth to sixth abdominal somites and telson, lateral; D, Telson, dorsal. CL, postorbital carapace length; NFRDI, National Fisheries Research and Development Institute. Scale bar: A-D=1 mm.

lobe of sixth somite triangular but not spiniform. Telson (Fig. 1C) with 2 pairs of small dorsolateral spines; posterior margin ending in minute median tooth, bearing 2 pairs of marginal spines and tuft of mesial setae. Eye (Fig. 1B) pyriform; cornea broader than eyestalk. Antennular peduncle (Fig. 1A, B) with first segment as long as distal 2 segments combined; second segment slightly longer than third; stylocerite truncate, reaching distal 1/3 of first segment of antennular peduncle. Antennal scale (Fig. 1A, B) overreaching distal margin of antennular peduncle; distolateral tooth falling short of blade; basicerite unarmed. Third maxilliped (Fig. 1A) stout, overreaching distal margin of antennular peduncle by distal 2 segments, without exopod; ultimate segment tapering to strong terminal tooth. First pereopods stout, asymmetrical; right chelate; left with simple dactylus, more slender than right. Second pereopods (Fig. 1D-F) slender, right longer than left; right (Fig. 1D) with 13-17 meral articles, 44-48 carpal articles, chela (Fig. 1E) with curved dactylus; left (Fig. 1F) with 5-7 meral articles, 16-18 carpal articles. Third and fourth pereopods (Fig. 1G) with ischia bearing 2 spines; meri with 1-3 spines; propodi with series of short setae in flexor margin, some tuft of long setae in margins of both of flexor and extensor. Fourth pereopod longer than third. Fifth pereopod (Fig. $1 \mathrm{H})$ with propodus bearing 25 small spines in flexor margin. Endopod of first male pleopod (Fig. 1I) with distal margin notched, lateral and mesial margins with 6-7 stout setae.

Distribution. Indo-West Pacific: eastern Africa to Japan, Philippines, Indonesia, Korea (present study); to a depth of $150 \mathrm{~m}$ (Chace, 1997).

Remarks. Chace (1997) established a new genus Hayashidonus for this single species generally known as Processa japonica, because the broadly triangular rostrum, the obscure or absent dorsolateral spines of the telson, and the exceptionally long molar process of the mandible seemed sufficiently 


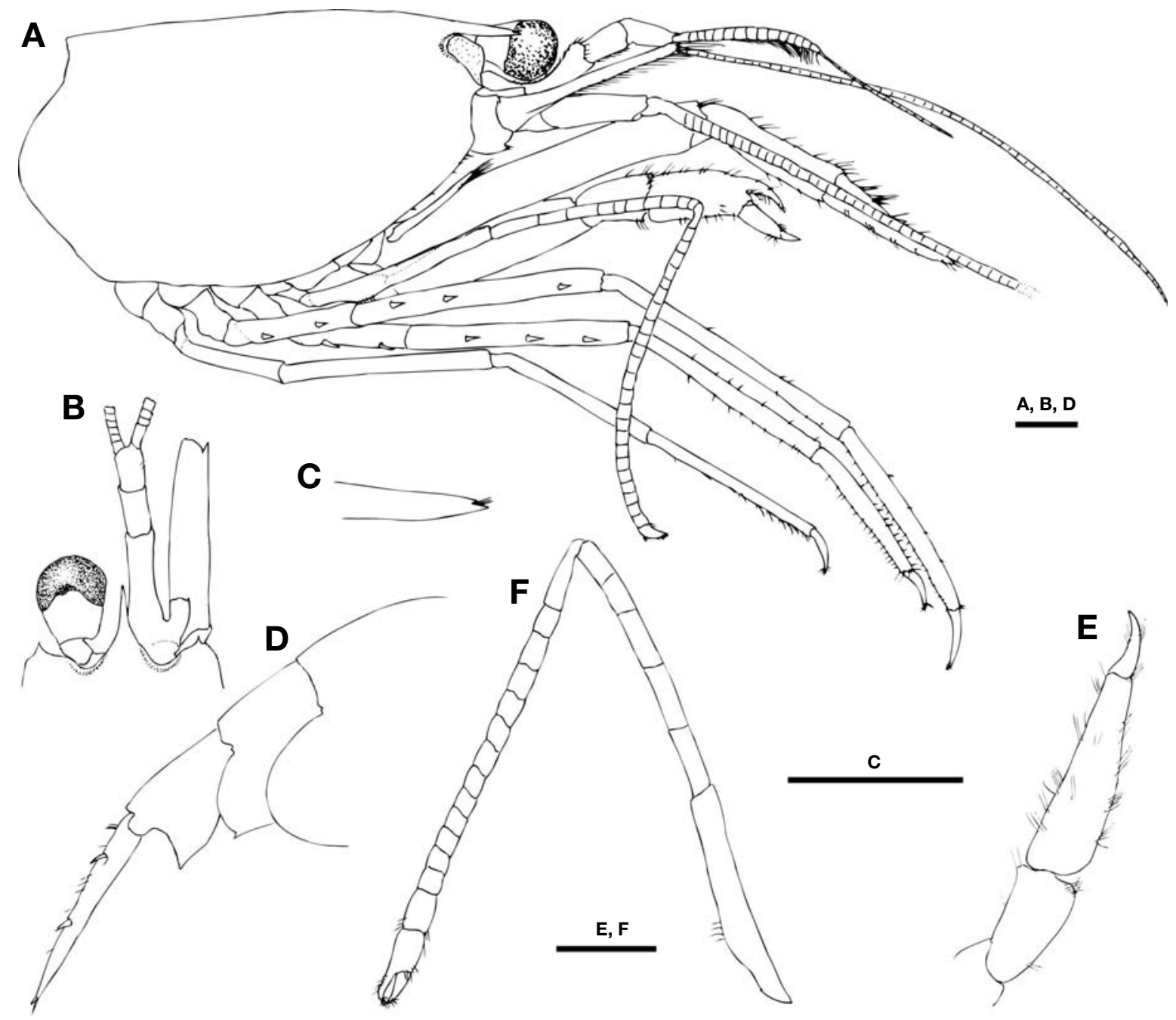

Fig. 3. Processa zostericola Hayashi, 1975. Ovigerous female (CL 6.1 mm, NFRDI 20110802-4) from Hamduok, Jeju-do. A, Carapace, cephalic and thoracic appendages, lateral; B, Anterior carapace and cephalic appendages, dorsal, right eye and left antennule and antenna omitted; C, Rostrum, lateral; D, Fourth to sixth abdominal somites and telson, lateral; E, Left first pereopod, lateral; F, Left second pereopod, lateral. CL, postorbital carapace length; NFRDI, National Fisheries Research and Development Institute. Scale bars: $\mathrm{A}-\mathrm{F}=1 \mathrm{~mm}$.

unusual among the processids. The present specimens agree well with the definitions of the species by Chace (1997) and Hayashi (1975) who magnificently reviewed the Indo-West Pacific Processidae.

Genus Processa Leach, 1815

\section{Processa sulcata Hayashi, 1975 (Fig. 2)}

\section{Restricted synonymy}

Processa sulcata Hayashi, 1975: 134, fig. 34 (type locality: Ainoshima, Fukuoka Pref., Kyushu, Japan) (see full synonymy); Noël, 1986: 291, fig. 19; Chace, 1997: 39; Cha et al., 2001: 123, 2 unnumbered figs.

Material examined. Korea: Gyeongsangnam-do: sex unknown 2 specimens (CL 2.5, $3.0 \mathrm{~mm}$ ), Geoje Island, Gujora, rough sand, dredge, 1 Nov 2001, Kim JN, NFRDI 201108023.

Description. Integument glabrous. Rostrum (Fig. 2A, B) relatively long, 0.21-0.25 times as long as carapace, slender in dorsal aspect, bifid distally, ventral margin slightly concave. Carapace (Fig. 2A, B) nearly smooth; postorbital region distinctly grooved; antennal spine distinct. Abdominal somites (Fig. 2C) smooth and rounded dorsally; pleura of first to fourth somites rounded posteriorly; pleuron of fifth somite 
with small posterior tooth; lateral lobe of sixth somite subtruncated. Telson (Fig. 2C, D) with 2 pairs of distinct dorsolateral spines; posterior margin ending in median tooth flanked by 2 pairs of spines and pair of setae. Eye (Fig. 2A, B) large; cornea moderately broader than eyestalk. Antennular peduncle (Fig. 2A, B) with distal segment of right and distal 2 segments of left missing; stylocerite obliquely truncate, falling short of midpoint of first segment of antennular peduncle. Antennal scale (Fig. 2A, B) with distolateral tooth not reaching blade; basicerite with smooth ventral margin. Third maxilliped (Fig. 2A) stout, overreaching distal margin of antennal scale by ultimate segment and distal 3/4 of penultimate segment, bearing well developed exopod. First pereopods (Fig. 2A) stout, asymmetrical; right with well developed chela, stouter than left; left simple, with claw-like dactylus. Second pereopods (Fig. 2A) slender; right missing; left with 5 meral and 14 carpal articles. Third pereopod (Fig. 2A) with ischium bearing 2 spines; merus with 4 spines. Fourth pereopod (Fig. 2A) longer than third pereopod; ischium bearing 2 spines; merus with 3 spines.

Distribution. Indo-West Pacific: South Africa, southern Arabia, Madagascar, Vietnam, Philippines, Japan, Korea; 0123 m (Chace, 1997).

Remarks. Although the present specimens are damaged and of undetermined sex, they agree with the original description of P. sulcata by Hayashi (1975) in the pleuron of the fifth abdominal somite with a posterior tooth, the basicerite of the antenna without any process, and the left second pereopod with 5 meral articles and 14 carpal articles. In Korea, Cha et al. (2001) first reported this species based on an ovigerous female collected from Hansan Island, Tongyeong.

1*Processa zostericola Hayashi, 1975 (Fig. 3)

Processa zostericola Hayashi, 1975: 137, fig. 35 (type locality: Tomioka Bay, Isl. Amakusa, Kumamoto Pref., Kyushu, Japan); Ledoyer, 1984: 43, fig. 21; Unsworth et al., 2010: 353 (list).

Material examined. Korea: Jeju-do: 1 우 (CL $6.9 \mathrm{~mm}), 1$ ovig. 우 (CL $6.1 \mathrm{~mm}$ ), Hamduok, Zostera belt, beam trawl, 10 Jun 1994, Kim JN, NFRDI 20110802-4.

Description. Integument glabrous. Rostrum (Fig. 3A-C) relatively short, 0.18-2.1 times as long as carapace, slender in dorsal aspect, bifid indistinctly distally, ventral margin nearly straight. Carapace (Fig. 3A, B) smooth except for postorbital region moderately grooved; antennal spine relatively strong. First to fourth abdominal somites (Fig. 3D) smooth and rounded; pleuron of fifth somite posteriorly pointed; lateral lobe of sixth somite subrectangular, unarmed. Telson
(Fig. 3D) with dorsolateral margin bearing 2 spines; posterior margin with minute median tooth, flanked by 2 pairs of small spines and pair of setae. Eye (Fig. 3A, B) moderately large, cornea slightly broader than eyestalk. Antennular peduncle (Fig. 3A, B) with first segment slightly longer than distal 2 segments combined; second segment subequal to third in length; stylocerite truncate, reaching basal third of first segment of antennular peduncle, lateral margin with minute tooth distally. Antennal scale (Fig. 3A, B) reaching distal margin of antennular peduncle; distolateral tooth falling slightly short of blade; basicerite with small obtuse process on anteroventral margin. Third maxilliped (Fig. 3A) stout, overreaching distal margin of antennal scale by distal 2 segments, well developed exopod present. First pereopods (Fig. 3A, E) stout, chelate on right, simple on left. Second pereopods (Fig. 3A, F) slender; right with 10 meral and 24 carpal articles; left with 5 meral and 14 carpal articles. Third and fourth pereopods (Fig. 3A) with 2 ischial and 3-6 meral spines; fourth pereopod longer than third. Fifth pereopod (Fig. 3A) more slender than third and fourth pereopods; ischium and merus lacking spines; propodus with 17-21 small spines on flexor margin.

Distribution. New Caledonia, Indonesia, Japan, Korea (present study); 0-8 m (Ledoyer, 1984).

Remarks. This speices is similar to $P$. sulcata in having the distinct antennal spine, the pleuron of fifth abdominal somite with a distinct posterior tooth, the truncate or rectangular lateral lobe of sixth abdominal somite, and the distally bifid rostrum. However, $P$. zostericola differs from $P$. sulcata in having an obtuse process of the basicerite of antenna on the anteroventral margin. In $P$. sulcata the basicerite of antenna lacks the process but is smooth on the ventral margin.

Key to Processidae species from Korean waters

1. Third maxilliped without exopod; rostrum triangular in dorsal aspect

Hayashidonus japonicus (De Haan, 1844)

- Third maxilliped with exopod; rostrum slender in dorsal

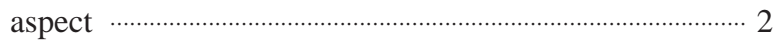

2. Basicerite of antenna smooth, without process on anteroventral margin ……….... Processa sulcata Hayashi, 1975

- Basicerite of antenna with obtuse anteroventral process ... Processa zostericola Hayashi, 1975

\section{ACKNOWLEDGEMENTS}

This work was funded by the National Fisheries Research and Development Institute (RP-2011-FR-031). We are also greatly indebted to Dr. Ken-Ichi Hayashi of the Shrimp and

Korean name: ${ }^{1 *}$ 잘피짧은뿔새우 (신칭) 
Prawn Research Laboratory, Shimonoseki, for his critical review of the manuscript.

\section{REFERENCES}

Cha HK, Lee JU, Park CS, Baik CI, Hong SY, Park JH, Lee DW, Choi YM, Hwang K, Kim ZG, Choi KH, Sohn H, Sohn MH, Kim DH, Choi JH, 2001. Shrimps of the Korean Waters. National Fisheries Research Development Institute, Busan, pp. 1-188.

Chace FA Jr, 1997. The caridean shrimps (Crustacea: Decapoda) of the Albatross Philippine Expedition, 1907-1910, Part 7: Families Atyidae, Eugonatonotidae, Rhynchocinetidae, Bathypalaemonellidae, Processidae, and Hippolytidae. Smithsonian Contributions to Zoology, 587:1-106.

De Grave S, Dean Pentcheff N, Ahyong ST, Chan TY, Crandall KA, Dworschak PC, Felder DL, Feldmann RM, Fransen CHJM, Goulding LYD, Lemaitre R, Low MEY, Martin JW, Ng PKL, Schweitzer CE, Tan SH, Tshudy D, Wetzer $\mathrm{R}, 2009$. A classification of living and fossil genera of decapod crustaceans. Raffles Bulletin of Zoology, Supplement (21):1-109.

De Haan W, 1833-1850. Crustacea. In: Fauna Japonica sive Descriptio Animalium, quae in Itinere per Japoniam, Jussu et Auspiciis Superiorum, qui Summum in India Batava Impe- rium Tenent, Suscepto, Annis 1823-1830 Collegit, Notis, Observationibus et Adumbrationibus Illustravit (Ed., von Siebold PF). Lugduni-Batavorum, Leiden, pp. 1-243, pls. A-J, L-Q, 1-55, circ. tab. 2.

Hayashi K, 1975. The Indo-West Pacific Processidae (Crustacea, Decapoda, Caridea). Journal of the Shimonoseki University of Fisheries, 24:47-145.

Holthuis LB, 1993. The recent genera of the Caridean and Stenopodidean shrimps (Crustaeca, Decapoda): with an appendix on the order Amphionidacea. Nationaal Natuurhistorisch Museum, Leiden, pp. 1-328.

Ledoyer M, 1984. Les Caridea (Crustacea, Decapoda) des herbiers de Phanérogames marines de Nouvelle-Calédonie (Région de Nouméa) (Systématiquee, écologie, variations nycthémèrales et vicariance). Zoologische Verhandelingen, 211: $1-58$.

Noël P, 1986. Crustacés Décapodes: Processidae de l'Indo-OuestPacifique. Mémoires du Muséum National d'Histoire Naturelle, Séries A, Zoologie, 133:261-301.

Unsworth RKF, De Grave S, Goulding LYD, 2010. Influence of environmental cycles upon a seagrass caridean shrimp assemblage. The Raffles Bulletin of Zoology, 58:349-355.

Received August 24, 2011

Revised October 6, 2011 Accepted November 8, 2011 